\title{
AN INVENTORY THE EQUIVALENTS OF THE LATEST FOREIGN-INDONESIAN TERM AS A MEANS OF INTRODUCING INDONESIAN TO FOREIGN SPEAKERS
}

\author{
Sudaryanto, Hermanto, dan Dedi Wijayanti \\ Universitas Ahmad Dahlan \\ e-mail: sudaryanto@pbsi.uad.ac.id
}

\begin{abstract}
This study aims to inventory the equivalent of the latest foreign-Indonesian term as a means of introducing Indonesian language to foreign speakers (BIPA). This research uses qualitative approach. Data is obtained through reading and noting the equivalents of foreignIndonesian terminology in dictionaries, books, and newspapers. This study uses content review techniques. The results of this study show about 5.800 equivalents of foreignIndonesian terms covering eight study areas namely, (1) business and finance, (2) tourism, (3) sport, (4) property, (5) transportation and communication, (6) industry, (7) beauty and personal equipment, and (8) information and electronics.
\end{abstract}

Keywords: inventory, equivalents of the latest foreign-Indonesian, BIPA

\section{PENDAHULUAN}

Secara historis, bahasa Indonesia bercikal-bakal dari bahasa Melayu, khususnya daerah Riau dan sekitarnya (bdk. Soeparno dkk, 1997: 1; Chaer, 2010: 1; Bowden, 2014: 106). Salah satu sifat bahasa Melayu adalah sangat terbuka dan mudah disesuaikan dengan perkembangan zaman, serta mendapatkan pengaruh dari luar. Yang dimaksudkan dengan mendapatkan pengaruh dari luar, yaitu bahasa Indonesia menyerap kosakata-kosakata dari bahasa asing. Sedikitnya terdapat 10 bahasa asing yang menyumbang kosakatanya bagi bahasa Indonesia, antara lain, bahasa Arab, Belanda, Cina, Inggris, Jerman, Latin, Perancis, dan Yunani (Sneddon, 2003: 185; Jones, 2008: vii; Samuel, 2008: 94-96).

Bahasa-bahasa asing tersebut telah menyumbang kosakatanya bagi bahasa Indonesia, dengan menyesuaikan kaidah dan ejaan bahasa Indonesia. Sebagai contoh, kata download (bahasa Inggris) memiliki padanan kata dalam bahasa Indonesia, unduh atau mengunduh. Padanan istilah asing-Indonesia itu belum banyak yang diketahui oleh masyarakat Indonesia, tak terkecuali mahasiswa asing yang sedang belajar bahasa Indonesia sebagai bahasa asing atau bahasa kedua (Indonesian language as a foreign language/second language), atau bisa disebut juga Bahasa Indonesia bagi Penutur Asing (BIPA) (bdk. Alwi, 2000: 117; Suyitno, 2010: 4; Sudaryanto, 2014: 66; Iskandarwassid \& Sunendar, 2015: 268).

Berdasarkan uraian di atas, penting kiranya dilakukan penelitian mengenai inventarisasi padanan istilah asing-Indonesia mutakhir sebagai sarana pengenalan bahasa Indonesia bagi penutur asing. Terkait itu, Badan Pengembangan dan Pembinaan Bahasa (Badan Bahasa) Kementerian Pendidikan dan Kebudayaan (Kemendikbud) telah rutin merilis infografis mengenai padanan istilah asing-Indonesia dan menerbitkan buku Pengindonesiaan Kata dan Ungkapan Asing (Sugono dkk, 2008). Meskipun demikian, kedua upaya tersebut dinilai belum cukup. Setidaknya perlu diterbitkan kamus ringkas atau glosarium padanan istilah asingIndonesia mutakhir yang jumlah, daftar, dan kosakatanya lebih akurat, dan terutama dapat diakses oleh penutur asing. 
Penerbitan kamus ringkas atau glosarium itu menjadi sarana untuk mengenalkan bahasa Indonesia di luar negeri. Kelak, melalui upaya itu kemudian dapat terwujud cita-cita bahasa Indonesia sebagai bahasa internasional, sebagaimana bunyi Pasal 44 ayat (1) Undang-Undang Nomor 24 Tahun 2009 tentang Bendera, Bahasa, dan Lambang Negara, serta Lagu Kebangsaan: "Pemerintah meningkatkan fungsi Bahasa Indonesia menjadi bahasa internasional secara bertahap, sistematis, dan berkelanjutan."

Dari aspek makna, kata padanan memiliki makna 'kata atau frasa dalam sebuah bahasa yang memiliki kesejajaran makna dengan kata atau frasa dalam bahasa lain, misalnya, maison dalam bahasa Perancis padanannya rumah dalam bahasa Indonesia' atau 'ekuivalen' (Sudaryanto, 2017:82). Dalam konteks seperti itu, diupayakan untuk menginventarisasi padanan istilah asingIndonesia mutakhir yang terdapat di buku, kamus, dan surat kabar berbahasa Indonesia. Terkait itu, tujuan penelitian ini adalah untuk menginventarisasi padanan istilah asingIndonesia mutakhir dan peluangnya sebagai sarana pengenalan bahasa Indonesia bagi penutur asing.

\section{METODE}

Pendekatan yang digunakan dalam penelitian adalah pendekatan kualitatif. Di dalam pendekatan tersebut, terdapat penelitian deskriptif yang memiliki data berupa kata-kata atau gambaran sesuatu. Deskripsi merupakan gambaran ciri-ciri data secara akurat sesuai dengan sifat alamiah itu sendiri. Dalam penelitian, data yang dianalisis, yaitu semua padanan istilah asing-Indonesia mutakhir yang terdapat di buku, kamus, dan surat kabar berbahasa Indonesia.

Pengumpulan data menggunakan peneliti sebagai instrumen utama. Hal ini sejalan dengan pemikiran bahwa tidak adanya kemungkinan memakai alat lain selain manusia (Djajasudarma, 2006: 12). Data yang dikumpulkan adalah padanan istilah asing-
Indonesia mutakhir yang terdapat di buku, kamus, dan surat kabar berbahasa Indonesia. Selanjutnya, data tersebut dikumpulkan dengan menggunakan teknik baca dan catat. Data dicatat dengan menggunakan kartu data.

Keabsahan data dalam penelitian dilakukan dengan dua konsep, yaitu konsep kesahihan (validitas) dan keterandalan (reliabilitas). Dalam penelitian, digunakan validitas semantik dan reliabilitas melalui cara baca dan kaji ulang. Untuk memperoleh data yang terpercaya, dilakukan tiga cara, yaitu ketekunan pengamatan, triangulasi, dan pengecekan teman sejawat. Teman sejawat dalam penelitian adalah Prof. Drs. Soeparno, dosen mata kuliah Linguistik Historis Komparatif pada Program Studi Pendidikan Bahasa dan Sastra Indonesia FKIP Universitas Ahmad Dahlan. Prof. Drs. Soeparno dipandang memiliki kemampuan yang baik di bidang ilmu perbandingan bahasa, termasuk padanan istilah asingIndonesia mutakhir.

Teknik analisis data dalam penelitian berupa teknik kajian isi (content analysis). Definisi kajian isi adalah teknik penelitian yang dimanfaatkan untuk menarik kesimpulan yang replikatif dan sahih dari data atas dasar konteksnya (Krippendorf, 1980: 21). Langkah selanjutnya, dilakukan penyusunan dan kategorisasi. Data yang terkumpul kemudian dipilah-pilah dan dikategorisasikan.

\section{HASIL DAN PEMBAHASAN}

Pada bagian ini, diuraikan hasil dan pembahasan tentang inventarisasi padanan istilah asing-Indonesia mutakhir sebagai sarana pengenalan bahasa Indonesia bagi penutur asing (BIPA). Hasil penelitian ini menunjukkan, tercatat sekitar 5.800 kata padanan istilah asing-Indonesia mutakhir, yang digunakan dalam delapan bidang usaha, yaitu (1) bisnis dan keuangan, (2) pariwisata, (3) olahraga, (4) properti, (5) perhubungan dan komunikasi, (6) industri, (7) kecantikan dan perlengkapan pribadi, serta (8) informasi dan elektronika. Untuk memudahkan 
pemelajar BIPA dalam mengenal kata padanan istilah asing-Indonesia mutakhir, peneliti menyusunnya ke dalam bentuk kamus ringkas atau glosarium padanan istilah asing-Indonesia, sesuai dengan abjad atau alfabetis.

Selanjutnya, diuraikan hasil dan pembahasan tentang inventarisasi padanan istilah asing-Indonesia mutakhir sebagai sarana pengenalan bahasa Indonesia bagi penutur asing (BIPA). Hasil penelitian menunjukkan, tercatat sekitar 5.800 kata padanan istilah asing-Indonesia mutakhir, yang digunakan dalam delapan bidang usaha, yaitu (1) bisnis dan keuangan, (2) pariwisata, (3) olahraga, (4) properti, (5) perhubungan dan komunikasi, (6) industri, (7) kecantikan dan perlengkapan pribadi, serta (8) informasi dan elektronika. Untuk memudahkan pemelajar BIPA dalam mengenal kata padanan istilah asing-Indonesia mutakhir, peneliti menyusunnya ke dalam bentuk kamus ringkas atau glosarium padanan istilah asing-Indonesia, sesuai dengan abjad atau alfabetis.

\section{Pembahasan}

Pada bagian berikut dibahas sejumlah kata padanan istilah asing-Indonesia mutakhir, sesuai dengan abjad atau alfabetis. Label-label bahasa, seperti Ing (bahasa Inggris), Per (bahasa Perancis), Lat (bahasa Latin), Jep (bahasa Jepang), dan Chi (bahasa China).

\section{A}

\begin{tabular}{ll} 
Asing & \multicolumn{1}{c}{ Indonesia } \\
ability to borrow (Ing) daya pinjam \\
$\begin{array}{ll}\text { ability to pay (Ing) } & \text { daya bayar } \\
\text { abnormal risk (Ing) } & \text { risiko } \\
\text { abnormal }\end{array}$ \\
$\begin{array}{ll}\text { absurd (Ing) } & \text { absurd } \\
\text { acceptance (Ing) } & \text { aksep(tasi) } \\
\text { acceptance test (Ing) } & \text { uji terima } \\
\text { access (Ing) } & \text { akses; masuk } \\
\text { access period (Ing) } & \text { periode akses } \\
\text { access time (Ing) } & \text { waktu akses } \\
\text { account (Ing) } & \text { akun; rekening }\end{array}$
\end{tabular}

$\begin{array}{ll}\begin{array}{l}\text { Asing } \\ \text { baby bond (Ing) }\end{array} & \begin{array}{l}\text { Indonesia } \\ \text { obligasi kecil } \\ \text { baby corn (Ing) }\end{array} \\ \begin{array}{l}\text { putren; jagung } \\ \text { muda } \\ \text { minyak bayi } \\ \text { baby oil (Ing) }\end{array} & \text { rekam cadang } \\ \text { back up (Ing) } & \text { aki; baterai } \\ \text { battery (Ing) } & \text { bazar } \\ \text { bazaar (Ing) } & \text { balok } \\ \text { beam (Ing) } & \text { sepeda } \\ \text { bicycle (Ing) } & \text { buket } \\ \text { bouquet (Ing)* } & \text { berita kilat; } \\ \text { bulletin (Ing) } & \text { buletin }\end{array}$

C

$\begin{array}{ll}\begin{array}{l}\text { Asing } \\ \text { cabaret (Ing) }\end{array} & \begin{array}{l}\text { Indonesia } \\ \text { kabaret; } \\ \text { panggung gembira }\end{array} \\ \text { cafe (Ing) } & \text { kafe } \\ \text { cafetaria (Ing) } & \text { kafetaria } \\ \text { canopy (Ing) } & \text { sengkuap; } \\ & \text { kanopi } \\ \text { cash (Ing) } & \mathbf{1} \text { uang tunai; } 2 \\ & \text { kas } \\ \text { clean (Ing) } & \text { anggung } \\ \text { client (Ing) } & \text { klien } \\ \text { commuter line (Ing)* } & \text { kereta komuter } \\ \text { coach (Ing)* } & \text { gerbong } \\ & \text { penumpang } \\ \text { copy paste (Ing)* } & \text { salin tempel }\end{array}$

\section{Asing}

data disk (Ing)

digit (Ing)

discount (Ing)

double (Ing)

draft (Ing)

dress (Ing)

drilling (Ing)

dry ice (Ing)

dubbing (Ing)

dumpling (Ing)

D

\section{Indonesia}

diska data

digit

potongan;

rabat;

diskonto; diskon

ganda

wesel

busana;

pakaian; gaun

pengeboran

es kering

sulih suara

pangsit

E

\section{Asing}

Indonesia 


\begin{tabular}{|c|c|c|c|}
\hline earphones (Ing) & $\begin{array}{l}\text { pelantang } \\
\text { telinga }\end{array}$ & & $\mathbf{H}$ \\
\hline ecotourism (Ing) & wisata & Asing & Indonesia \\
\hline & lingkungan; & hacking jacket (Ing) & jaket joki \\
\hline & ekowisata & hacksaw (Ing) & gergaji besi \\
\hline editorial page (Ing) & halaman & hair bleacher (Ing) & pewarna \\
\hline & editorial & & rambut \\
\hline enter (Ing) & masuk; enter & hashtag (Ing)* & tagar; tanda pagar \\
\hline entrance (Ing) & (pintu) masuk & hiking (Ing) & (olahraga) kelana alam \\
\hline error (Ing)* & galat & hill (Ing) & bukit \\
\hline extra bed (Ing) & ranjang ekstra; ranjang & home (Ing)* & beranda \\
\hline & tambahan & hotline (Ing) & salur(an) siaga \\
\hline eye liner (Ing) & pemalis mata & human resources (Ing) & sumber daya manusia \\
\hline eye make-up (Ing) & tata rias mata & & (SDM) \\
\hline eye stick (Ing) & batang mata & hypermarket (Ing) & hipermarket \\
\hline & $\mathbf{F}$ & & I \\
\hline Asing & Indonesia & Asing & Indonesia \\
\hline fabricated news (Ing) & $\begin{array}{l}\text { berita buatan; } \\
\text { berita rekaan }\end{array}$ & $\begin{array}{l}\text { ice cream cone (Ing) } \\
\text { icon (Ing) }\end{array}$ & $\begin{array}{l}\text { contong eskrim } \\
\text { ikon }\end{array}$ \\
\hline facade (Ing) & $\begin{array}{l}\text { muka } \\
\text { bangunan }\end{array}$ & indent (Ing) & $\begin{array}{l}\text { pesan beli; } \\
\text { inden }\end{array}$ \\
\hline facsimile (Ing) & faksimile & install (Ing) & pasang \\
\hline fair (Ing) & pekan raya & instant (Ing) & semerla; dadak; instan \\
\hline fans (Ing) & penggemar & interlude (Ing) & selingan \\
\hline favorite (Ing) & favorit & intermezzo (Ing) & intermeso \\
\hline feature news (Ing) & berita khas & isolator (Ing) & isolator; isolasi \\
\hline finish (Ing) & $\begin{array}{l}\text { (garis) akhir; } \\
\text { finis }\end{array}$ & $\begin{array}{l}\text { issuer (Ing) } \\
\text { itinerary (Ing) }\end{array}$ & $\begin{array}{l}\text { emiten; penerbit efek } \\
\text { rute perjalanan }\end{array}$ \\
\hline flatcar (Ing)* & gerbong datar & & \\
\hline frequently & & & $\mathbf{J}$ \\
\hline asked questions (Ing)* & $\begin{array}{l}\text { soal sering } \\
\text { ditanya }\end{array}$ & $\begin{array}{l}\text { Asing } \\
\text { jab (Ing) } \\
\text { jack (Ing) }\end{array}$ & $\begin{array}{l}\text { Indonesia } \\
\text { paraf } \\
\text { dongkrak; } \\
\text { pengungkit }\end{array}$ \\
\hline Asing & Indonesia & jacket (Ing) & jas; jaket \\
\hline gadget (Ing)* & acang; gawai & jackfruit (Ing) & nangka \\
\hline gag(line) (Ing) & (ucapan) & jasmine oil (Ing) & minyak melati \\
\hline & lelucon & jazz music (Ing) & musik jaz \\
\hline gain (Ing) & keuntungan & junior suite (Ing) & suit junior \\
\hline game (Ing) & $\begin{array}{l}\text { permainan; } \\
\text { gim }\end{array}$ & junk bond (Ing) & obligasi berisiko \\
\hline golden age (Ing)* & $\begin{array}{l}\text { gim } \\
\text { masa kencana }\end{array}$ & $\begin{array}{l}\text { jurnalist (Ing) } \\
\text { jury (Ing) }\end{array}$ & $\begin{array}{l}\text { wartawan } \\
\text { juri }\end{array}$ \\
\hline grade crossing (Ing)* & jalur persilangan & & \\
\hline guard (Ing) & pengawal; pelindung; & & $\mathbf{K}$ \\
\hline & garda & Asing & Indonesia \\
\hline guest house (Ing) & wisma tamu; mes & keel (Ing) & lunas (kapal) \\
\hline guest room (Ing) & kamar tamu (hotel); & kerosine (Ing) & minyak tanah \\
\hline & ruang tamu & keyboard (Ing) & papan tombol \\
\hline guide (Ing) & pemandu & key case (Ing) & gantungan \\
\hline
\end{tabular}




\begin{tabular}{|c|c|}
\hline & kunci \\
\hline key news (Ing) & berita inti; berita utama \\
\hline king (Ing) & raja; king \\
\hline king of pop (Ing) & raja (musik) pop \\
\hline knee pad (Ing) & pelindung lutut \\
\hline knee socks (Ing) & kaus kaki selutut \\
\hline \multirow[t]{2}{*}{ kwee tiaw (Chi) } & kuetiau \\
\hline & $\mathbf{L}$ \\
\hline Asing & Indonesia \\
\hline labor cost (Ing) & biaya kerja \\
\hline la carte $($ Per $)$ & $\begin{array}{l}\text { la carte; } \\
\text { manasuka }\end{array}$ \\
\hline land (Ing) & lahan \\
\hline laptop computer & $\begin{array}{l}\text { (Ing) komputer laptop; } \\
\text { komputer jinjing }\end{array}$ \\
\hline laundry (Ing)* & penatu \\
\hline
\end{tabular}

light rapit transit (Ing)* kereta ringan terpadu

locker (Ing)
log book (Ing)
lunch (Ing)
lychee (Ing)

(KRT)

loker

buku log

santap siang

leci

$\begin{array}{ll}\text { Asing } & \text { M } \\ \text { mah-jong (Chi) } & \text { Indonesia } \\ \text { mail box (Ing) } & \text { kohyong } \\ \text { mail carrier (Ing) } & \text { tukang pos } \\ \text { mail service (Ing) } & \text { layanan pos } \\ \text { mailing (Ing) } & \text { pengiriman pos } \\ \text { mailing list (Ing) } & \text { daftar (alamat) kirim } \\ \text { maisonette (Per) } & \text { maisonet } \\ \text { maitre d' (Per) } & \text { pramutama; maitre } \\ \text { marketing (Ing) } & \text { pemasaran } \\ \text { mass rapid transit (Ing)* moda raya } \\ & \text { terpadu (MRT) } \\ & \text { N } \\ \text { Asing } & \text { Indonesia } \\ \text { narration (Ing) } & \text { kisahan; narasi } \\ \text { narator (Ing) } & \text { pengisah; narator } \\ \text { national park (Ing) } & \text { taman nasional } \\ \text { netizen (Ing)* } & \text { warganet } \\ \text { network (Ing) } & \text { jaringan; } \\ & \text { jejaring } \\ \text { news editor (Ing) } & \text { penyunting berita } \\ \text { news flash (Ing) } & \text { kilas berita } \\ \text { noodle (Ing) } & \text { mi } \\ \text { normal cost (Ing) } & \text { biaya normal } \\ & \end{array}$

notebook (Ing) komputer pangku;

komputer laptop

Asing
oar (Ing)
oarsman (Ing)
orange (Ing)
orchestra (Ing)
order (Ing)
output (Ing)
ostokemono (Jep)
overhead (Ing)
overpass (Ing)
oxygen mask (Ing)

\section{O}

Indonesia

dayung

pendayung

jeruk manis

orkestra

pesanan; order

(ke)luaran

acar ala

Jepang

pukulan atas kepala

lintas atas

masker oksigen

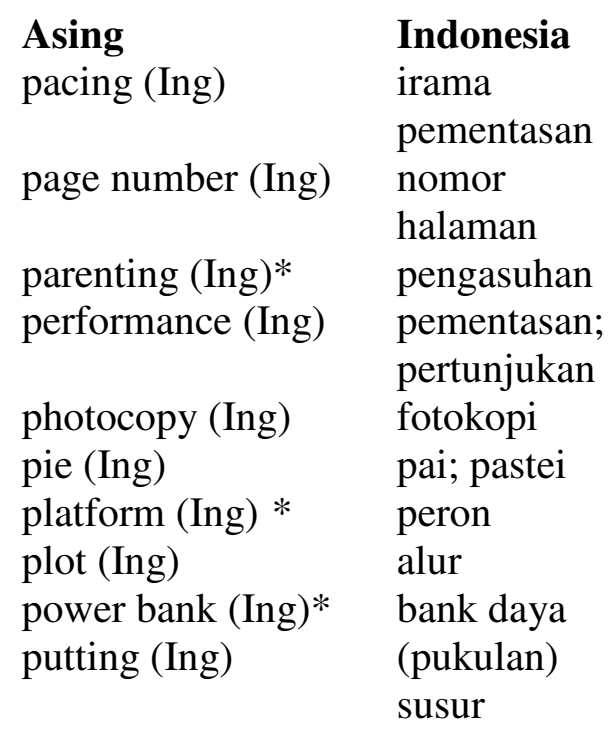

Q

Asing Indonesia

quality control (Ing) kendali mutu quantity variance (Ing) variansi

quay (Ing)

quay (Ing) dermaga; kade

queen (Ing) perdana

quick asset (Ing) aset cepat

quick lunch (Ing) makan siang cepat

quill brush (Ing) sikat bulu

quiver (Ing) tempat anak panah

quota (Ing) kuota

quotation (Ing) kutipan; penawaran 


Asing
racer glove (Ing)
racket (Ing)
radio beacon (Ing)
radio beam (Ing)
raincoat (Ing)
review (Ing)*
roadrailer (Ing)*
route (Ing)
rowing (Ing)
runway (Ing)*

\section{Indonesia}

sarung tangan balap

raket

menara radio

pancaran radio

jas hujan

tinjauan

gerbong trailer

rute

(olahraga) dayung

landas pacu

\section{S}

Asing
saffron (Ing)
salary (Ing)
siding (Ing)*
stapler (Ing)*
stakeholder (Ing)*
steward (Ing)*
stewardess (Ing)*
subtitle (Ing)*
subway (Ing)*
switch (Ing)*

\section{Indonesia}

kunyit

gaji

jalur

persilangan

pengokot

pemangku

kepentingan

pramugara

pramugari

sulih teks

kereta bawah

tanah

wesel

\section{T}

\section{Asing}

table lamp (Ing)

tackle (Ing)

tape (Ing)

target (Ing)

telegram (Ing)

telegraph (Ing)

tie (Ing)*

Indonesia

lampu meja

1 merempuh (OR); 2

menangani

pita; tep

sasaran

telegram

(berita);

kawat

petugas telegram; juru telegram

bantalan

kereta

timeline (Ing)* lini masa

train dispatcher (Ing)* pengatur

perjalanan

kereta api (PPKA)

type of fuel (Ing) jenis bahan

bakar

U

$\begin{array}{ll}\begin{array}{l}\text { umbrella (Ing) } \\ \text { underwriter (Ing) } \\ \text { uniform (Ing) }\end{array} & \begin{array}{l}\text { payung } \\ \text { penjamin } \\ \text { (pakaian) } \\ \text { seragam } \\ \text { biaya satuan; biaya per } \\ \text { unit }\end{array} \\ \text { unit cost (Ing) } & \text { pemutakhiran } \\ \text { update (Ing) } & \text { peningkatan (mutu) } \\ \text { upgrade (Ing) } & \text { jotos runjam } \\ \text { upper cut (Ing) } & \text { geladak atas } \\ \text { upper deck (Ing) } & \text { perselerakan kota } \\ \text { urban sprawl (Ing) } & \text { tas serbaguna; tas } \\ \text { utility case (Ing) } & \text { pernik }\end{array}$

Asing

V

vacancy (Ing)

Indonesia

lowongan

(kerja)

vacuum cleaner (Ing) pengisap debu

vacuum flask (Ing)

vest (Ing)

termos

rompi; ves

village (Ing)

dukuh; grama

VIP (very important person) (Ing)

naratama;

orang

visa (Ing) visa

voice mail (Ing) surat suara

void (Ing)

voucher (Ing)*

ruang lempang

kupon; voucer

W

Asing

waffle baker (Ing)

wage (Ing)

waiter (Ing)

waiting list (Ing)

walkout (Ing)

walkover (Ing)

website (Ing)

weekender (Ing)

workroom (Ing)

worksheet (Ing)

Asing

yacht (Ing)

yakiniku (Jep)

\section{Indonesia}

pemanggang wafel

upah

pramusaji

daftar tunggu

menang tanpa tanding

sarang (situs); laman

kopor akhir pekan;

kopor kecil

ruang kerja

lembar kerja

Y

Indonesia

kapal pesiar

yakiniku;

daging sapi

sayur-saus mogok tanding 


\begin{tabular}{|c|c|c|}
\hline yakitori (Jep) & $\begin{array}{l}\text { yakitori; sate } \\
\text { bawang }\end{array}$ & ayam- \\
\hline y-class (Ing) & kelas ekonomi & \\
\hline yeast (Ing) & ragi; khamir & \\
\hline yellow pages (Ing) & $\begin{array}{l}\text { lembar kuning } \\
\text { telepon) }\end{array}$ & (buku \\
\hline yellow paper (Ing) & koran kuning & \\
\hline yen bond (Ing) & obligasi yen & \\
\hline yogurt (Ing) & yogurt & \\
\hline \multirow[t]{2}{*}{ young designer (Ing) } & perancang muda & \\
\hline & $\mathbf{Z}$ & \\
\hline Asing & Indonesia & \\
\hline zalacca edulis (Lat) & salak & \\
\hline zebra crossing (Ing) & $\begin{array}{l}\text { penyeberangan } \\
\text { pejalan }\end{array}$ & \\
\hline zest (Ing) & irisan (kulit) & \\
\hline & $\begin{array}{l}\text { jeruk; kulit } \\
\text { jeruk }\end{array}$ & \\
\hline zinc industry (Ing) & industri seng & \\
\hline zipper (Ing) & $\begin{array}{l}\text { seleret; } \\
\text { resleting }\end{array}$ & \\
\hline \multicolumn{3}{|c|}{ zoological garden (Ing) kebun } \\
\hline & $\begin{array}{l}\text { binatang; } \\
\text { margasatwa }\end{array}$ & taman \\
\hline zoom in (Ing) & zum surut & \\
\hline zoom out (Ing) & zum maju & \\
\hline zucchini (Ing) & zukini & \\
\hline
\end{tabular}

Kosakata-kosakata yang diberikan tanda bintang (*) termasuk ke dalam kategori istilah asing mutakhir, khususnya dari bahasa Inggris, dan padanan Indonesianya. Disebut mutakhir karena kosakata-kosakata tersebut muncul akibat perkembangan teknologi informasi dan komunikasi yang pesat, seperti halnya internet. Berkat internet, kita dapat mengenal sejumlah kosakata asing dan padanan Indonesianya, seperti netizen-warganet, download-unduh, dan upload-unggah.

Selain itu, sebagai tambahan informasi, pihak Badan Bahasa dan Balai/Kantor Bahasa telah menerbitkan serial infografis padanan istilah asing-Indonesia. Infografis tersebut terbagi ke dalam beberapa judul, yaitu "Padanan Istilah", "Istilah Hari Ini", "Tahukah Anda?", dan "Kata Kita Pekan Ini". Tiap-tiap judul infografis berisikan kosakata asing dan padanan Indonesianya, serta gambar pendukung atau kalimat penyerta kosakata terkait. Melalui infografis tersebut, Badan Bahasa dan Balai/Kantor Bahasa melakukan upaya pembinaan bahasa Indonesia, khususnya padanan istilah asing-Indonesia mutakhir.

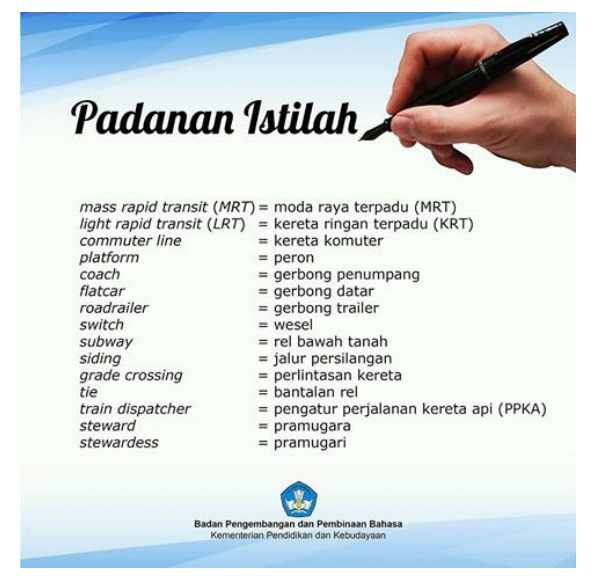

Gambar 1: Infografis Padanan Istilah

Gambar 1 menyampaikan 15 kosakata asing dari bahasa Inggris dan padanan Indonesianya, terutama dari bidang transporttasi darat (kereta) dan udara (pesawat terbang). Kosakata asing di bidang transportasi darat (kereta) dan padanan Indonesianya, seperti mass rapid transit (MRT) menjadi moda raya terpadu (MRT) dan light rapid transit (LRT) menjadi kereta ringan terpadu (KRT).

Sementara itu, kosakata asing di bidang transportasi udara (pesawat terbang) dan padanan Indonesianya, seperti steward menjadi pramugara dan stewardess menjadi pramugari.

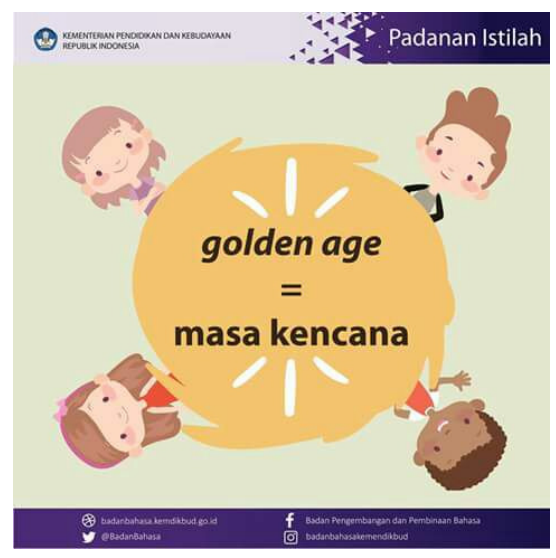


Gambar 2: Infografis Padanan Istilah Golden Age

Gambar 2 menyampaikan kosakata asing golden age dan padanan Indonesianya, masa kencana. Kosakata tersebut berasal dari bahasa Inggris dan digunakan dalam bidang pendidikan anak usia dini (PAUD). Para pendidik dan orangtua yang memiliki anakanak usia dini, khususnya usia 0-5 tahun, perlu diperkenalkan dengan kata golden age dan padanan Indonesianya, masa kencana.

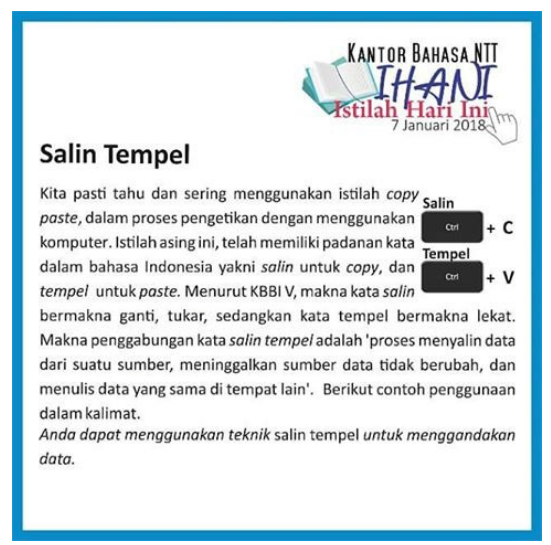

Gambar 3: Infografis Istilah Hari Ini Salin Tempel

Gambar 3 menyampaikan istilah asing copy paste dan padanan Indonesianya, salin tempel. Menurut Kamus Besar Bahasa Indonesia (KBBI) Edisi V, kata salin bermakna 'ganti', 'tukar', sedangkan kata tempel bermakna 'lekat'. Makna penggabungan kata salin tempel adalah 'proses menyalin data dari suatu sumber, meninggalkan sumber data tidak berubah, dan menulis data yang sama di tempat lain'. Berikut contoh penggunaan dalam kalimat. Anda dapat menggunakan teknik salin tempel untuk menggandakan data.

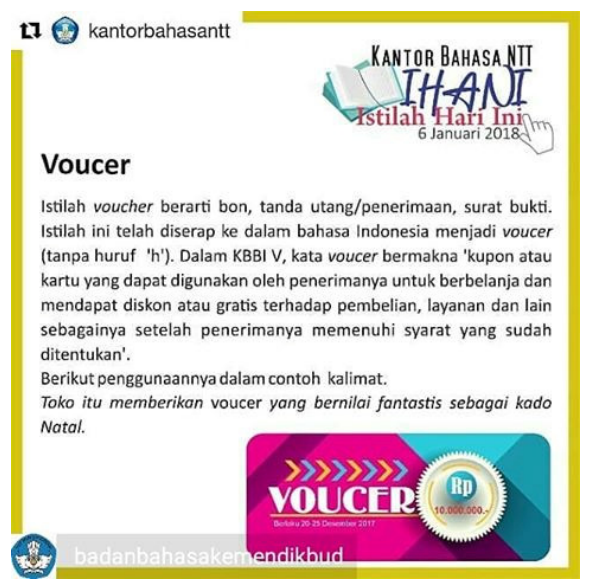

Gambar 4: Infografis Istilah Hari Ini Voucer

Gambar 4 menyampaikan istilah asing voucher dan padanan Indonesianya, voucer. Istilah voucher berarti 'bon', 'tanda utang/ penerimaan', dan 'surat bukti'. Istilah ini telah diserap ke dalam bahasa Indonesia menjadi voucer (tanpa huruf ' $h$ '). Dalam KBBI Edisi V, kata voucer bermakna 'kupon atau kartu yang dapat digunakan oleh penerimanya untuk berbelanja dan mendapat diskon atau gratis terhadap pembelian, layanan dan lain sebagainya setelah penerimanya memenuhi syarat yang sudah ditentukan'. Berikut penggunaannya dalam contoh kalimat. Toko itu memberikan voucer yang bernilai fantastis sebagai kado Natal.
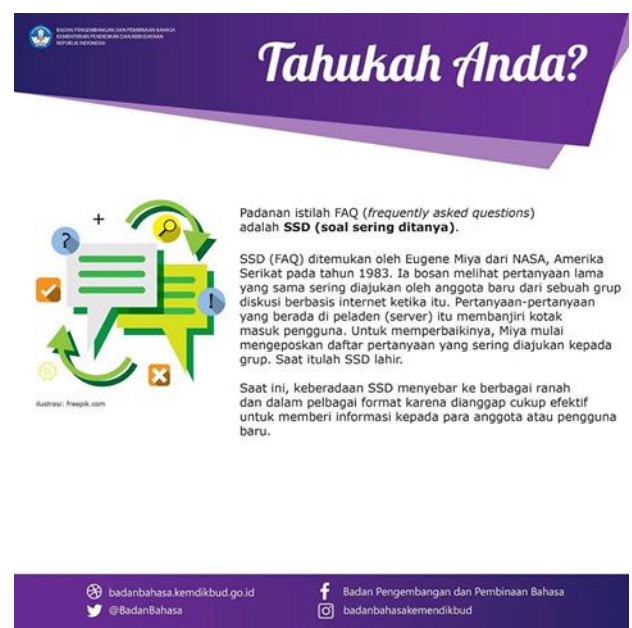

Gambar 5: Infografis Tahukah Anda Soal Sering Ditanya

Gambar 5 menyampaikan padanan istilah asing frequently asked questions (FAQ) 
dan padanan Indonesianya, soal sering ditanya (SSD). SSD (FAQ) ditemukan oleh Eugene Miya dari NASA, Amerika Serikat, pada tahun 1983. Ia bosan melihat pertanyaan lama yang sama sering diajukan oleh anggota baru dari sebuah grup diskusi berbasis internet ketika itu. Pertanyaan-pertanyaan yang berada di peladen (server) itu membanjiri kotak masuk pengguna. Untuk memperbaikinya, Miya mulai mengeposkan daftar pertanyaan yang sering diajukan kepada grup. Saat itulah SSD lahir. Saat ini, keberadaan SSD menyebar ke berbagai ranah dan dalam pelbagai format karena dianggap cukup efektif untuk memberi informasi kepada para anggota atau pengguna baru.

Selain itu, ada pula infografis "Kata Kita Pekan Ini" yang menampilkan istilah asing dan padanan Indonesianya. Sebagai contoh, istilah asing hashtag dan padanan Indonesianya, tanda pagar (diakronimkan menjadi tagar) pada Gambar 6.

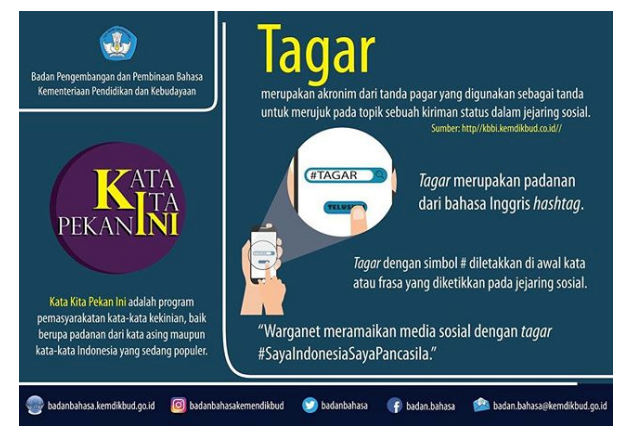

Gambar 6: Infografis Kata Kita Pekan Ini Tagar

Gambar 6 menyampaikan istilah asing hashtag dan padanan Indonesianya, tanda pagar (diakronimkan menjadi tagar). Tagar merupakan akronim dari tanda pagar yang digunakan sebagai tanda untuk merujuk pada topik sebuah kiriman status dalam jejaring sosial. Tagar dengan simbol \# diletakkan di awal kata atau frasa yang diketikkan pada jejaring sosial. Contohnya, warganet meramaikan media sosial dengan tagar \#SayaIndonesiaSayaPancasila.
Selain tagar, ada pula istilah lini masa dan warganet. Istilah lini masa merupakan padanan dari timeline pada Gambar 7. Istilah warganet merupakan padanan dari netizen pada Gambar 8. Timeline dan netizen berasal dari bahasa Inggris, seperti halnya hashtag.

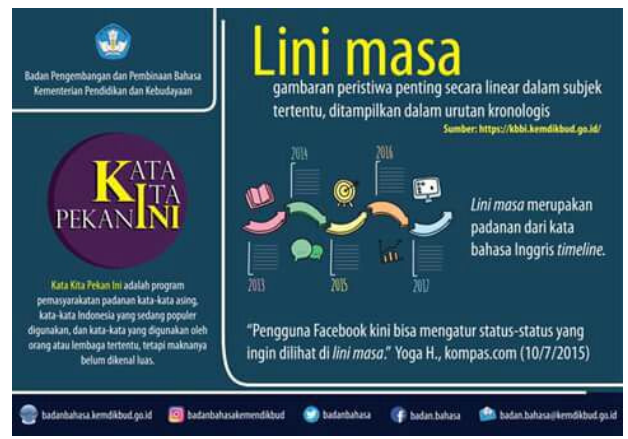

Gambar 7: Infografis Kata Kita Pekan Ini Lini Masa

Gambar 7 menyampaikan istilah asing timeline dan padanan Indonesianya, lini ma$s a$. Lini masa merupakan gambaran peristiwa penting secara linear dalam subjek tertentu, ditampilkan dalam urutan kronologis. Contohnya dalam kalimat yang berbunyi, Pengguna Facebook kini bisa mengatur statusstatus yang ingin dilihat di lini masa.

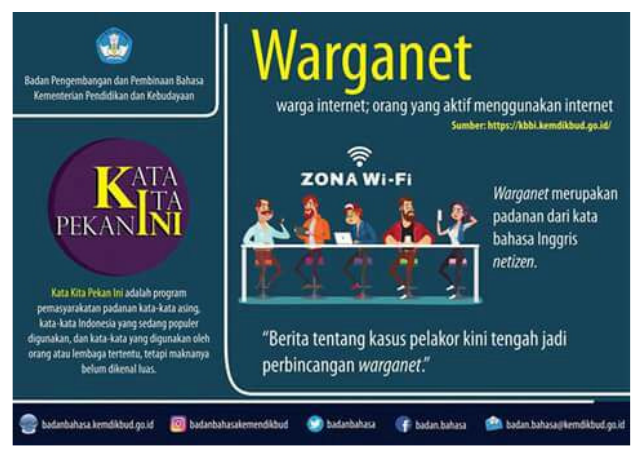

Gambar 8: Infografis Kata Kita Pekan Ini Warganet

Gambar 8 menyampaikan istilah asing netizen dan padanan Indonesianya, warganet (dari akronim warga internet). Warganet merupakan orang yang aktif menggunakan internet. Contohnya pada kalimat yang berbunyi, Berita tentang kasus pelakor kini tengah jadi perbincangan pelakor. 
Hasil penelitian Bowden (2013) mengonfirmasi perbandingan situasi kebahasaan antara Papua Nugini dan Indonesia. Papua Nugini memiliki 836 buah bahasa daerah, sedangkan Indonesia memiliki 706 buah bahasa daerah. Namun demikian, hasil penelitian Bowden belum sepenuhnya menjelaskan penggunaan istilah asing dan padanan Indonesianya, yang digunakan di Indonesia. Hal serupa juga ditemukan pada hasil penelitian Sudaryanto (2014) yang mengonfirmasi program Bahasa Indonesia bagi Penutur Asing (BIPA) di Tiongkok. Dalam praktik pengajarannya di Negeri Tirai Bambu itu, dosen BIPA baru sampai tahap mengajarkan kosakata Indonesia dan belum mengajarkan kosakata asing dan padanan Indonesianya.

Guna melengkapi kekurangan dari hasil penelitian Bowden dan Sudaryanto di atas, tulisan ini menyampaikan informasi tentang inventarisasi padanan istilah asing-Indonesia mutakhir sebagai sarana pengenalan bahasa Indonesia bagi penutur asing (BIPA). Secara alfabetis, disusun kosakata-kosakata asing, terbanyak dari bahasa Inggris, berikut padanan Indonesianya. Kosakata-kosakata tersebut terambil dari naskah yang sedang kami susun, Kamus Padanan Istilah AsingIndonesia.

Kamus tersebut merupakan salah satu luaran (output) dari penelitian yang sedang kami kerjakan, "Inventarisasi Padanan Istilah Asing Mutakhir dalam Bahasa Indonesia sebagai Sarana Pengenalan Bahasa Indonesia bagi Penutur Asing di Yogyakarta". Penelitian tersebut memperoleh Hibah Skim Penelitian Dosen Pemula (PDP) dari Direktorat Riset dan Pengabdian Masyarakat (DRPM), Kementerian Riset, Teknologi, dan Pendidikan Tinggi (Kemenristekdikti) dengan kontrak penelitian Nomor 109/SP2H/LT/ DRPM/2018.

\section{SIMPULAN}

Berdasarkan uraian hasil dan pembahasan di atas, diperoleh dua hal sebagai simpulan. Pertama, padanan istilah asingIndonesia mutakhir mencapai sekitar 5.800 kata, yang digunakan dalam delapan bidang usaha, yaitu (1) bisnis dan keuangan, (2) pariwisata, (3) olahraga, (4) properti, (5) perhubungan dan komunikasi, (6) industri, (7) kecantikan dan perlengkapan pribadi, dan (8) informasi dan elektronika. Kedua, padanan istilah asing-Indonesia mutakhir dapat disusun ke dalam kamus ringkas atau glosarium sesuai dengan alfabetis (A-Z), serta digunakan sebagai sarana pengenalan bahasa Indonesia bagi penutur atau pemelajar asing.

Pengenalan bahasa Indonesia bagi penutur asing menggunakan sarana berupa kamus, dalam hal ini Kamus Padanan Istilah AsingIndonesia, dan infografis istilah asing dan padanan Indonesianya, yang diterbitkan oleh Badan Bahasa dan Kantor Bahasa, seperti "Padanan Istilah", "Istilah Hari Ini", "Tahukah Anda?", dan "Kata Kita Pekan Ini”. Melalui kedua sarana itu, kelak diharapkan pemelajar asing yang sedang belajar bahasa Indonesia dapat lebih mudah memahami istilah asing dan padanan Indonesianya. 


\section{DAFTAR PUSTAKA}

Alwi, Hasan. 2000. Bahasa Indonesia: Pemakai dan Pemakaiannya. Jakarta: Departemen Pendidikan Nasional.

Bowden, Frederick John. 2013. Language and Basic Education in Indonesia. Linguistik Indonesia, 31 (1): 1-13.

Chaer, Abdul. 2010. Telaah Bibliografi Kebahasaan Bahasa Indonesia/Melayu. Jakarta: Rineka Cipta.

Djajasudarma, T. Fatimah. 2006. Metode Linguistik: Ancangan dan Kajian. Bandung: Refika Aditama.

Iskandarwassid \& Dadang Sunendar. 2015. Strategi Pembelajaran Bahasa. Bandung: Sekolah Pascasarjana UPI bekerja sama dengan PT Remaja Rosdakarya.

Jones, Russell (ed.). 2008. Loan-Words in Indonesian and Malay. Jakarta: Yayasan Obor Indonesia bekerja sama dengan KITLV-Jakarta.

Krippendorf, Klaus. 1980. Content Analysis: An Introduction to Its Methodology. Beverly Hills-London: Sage Publications.

Samuel, Jérome. 2008. Kasus Ajaib Bahasa Indonesia? Pemodernan Kosakata dan Politik Peristilahan. Terjemahan Dhany Saraswati Wardhany. Jakarta: KPG bekerja sama dengan École française d'Extrême-Orient, Pusat Bahasa-Departemen Pendidikan Nasional, dan Forum Jakarta-Paris.

Sneddon, James. 2003. The Indonesian Language: Its History and Role in Modern Society. Sydney: UNSW Press.

Soeparno, Haryadi, dan Suhardi. 1997. Bahasa Indonesia untuk Ekonomi. Yogyakarta: Ekonisia.

Sugono, dkk. 2008. Pengindonesiaan Kata dan Ungkapan Asing. Jakarta: Departemen Pendidikan Nasional.

Sudaryanto. 2014. BIPA di Mata Badan Bahasa: Pemutakhiran Peta Penyelenggara Program BIPA di Tiongkok pada Laman Badan Bahasa. Bahastra, 32 (1): 65-80.

Sudaryanto. 2017. Kamus Umum Bahasa dan Ilmu Bahasa (KUBIB). Yogyakarta: Samudra Biru.

Suyitno, Imam. 2010. "Pengembangan Materi Pembelajaran BIPA Berdasarkan Tujuan

Belajar Pelajar Asing." Pidato Pengukuhan Guru Besar dalam Bidang Ilmu Pembelajaran

Bahasa pada Fakultas Sastra Universitas Negeri Malang (UM). 